\section{Direct Examination}

Robert L. Heilbronner

Chicago Neuropsychology Group, Chicago, IL, USA

\section{Definition}

A trial deposition or live trial testimony consists of two phases: direct examination and crossexamination. The direct examination precedes the cross-examination and is conducted by the retaining attorney. In the first part of this examination, the retaining attorney attempts to demonstrate the qualifications of the expert witness. Thus, for a neuropsychology expert witness, questions are centered on academic degrees, relevant neuropsychological coursework, pre- and postdoctoral training in neuropsychology, employment history, other relevant experiences, and peer-reviewed scientific publications. At times, opposing counsel may challenge the credentials of the expert witness during the direct examination by requesting the court to voir dire the expert witness. Voir dire means to tell the truth and in a legal sense refers to additional questions intended to further assess one's competence to testify.
Thereafter, a trial judge decides whether the testimony of the expert witness is to be permitted. Once the judge permits the testimony, questioning by the retaining attorney continues and now focuses on open-ended questions that are intended to evoke succinct answers in favor of the retaining attorney's arguments. Once all questions are asked, the next phase of the trail deposition or live trial testimony, the cross-examination, ensues.

\section{Cross-References}

Cross-Examination

- Voir Dire

\section{References and Readings}

Greiffenstein, M. F., \& Cohen, L. (2005). Neuropsychology and the law: Principles of productive attorneyneuropsychologist relations. In G. Larrabee (Ed.), Forensic neuropsychology: A scientific approach. New York: Oxford University Press.

Melton, G. B., Petrila, J., Poythress, N. G., \& Slobogin, C. (2007). Psychological evaluations for the courts: A handbook for mental health professionals and lawyers (3rd ed.). New York: Guilford Press. 